\title{
Preconception health behaviors associated with pregnancy planning status among Brazilian women
}

\author{
Preparo pré-concepcional entre mulheres brasileiras e a \\ relação com o planejamento da gravidez \\ Preparación pre concepcional entre mujeres brasileñas y \\ la relación con la planificación del embarazo
}

\author{
Ana Luiza Vilela Borges ${ }^{1}$, Osmara Alves dos Santos², Natália de Castro Nascimento², Christiane Borges do Nascimento \\ Chofakian², Flávia Azevedo Gomes-Sponholz ${ }^{3}$
}

\section{How to cite this article:}

Borges ALV, Santos OA, Nascimento NC, Chofakian CBN, Gomes-Sponholz FA. Preconception health behaviors associated with pregnancy planning status among Brazilian women. Rev Esc Enferm USP. 2016;50(2):208-215. DOI: http://dx.doi.org/10.1590/S0080-623420160000200005

${ }^{1}$ Universidade de São Paulo, Escola de Enfermagem, Departamento de Enfermagem em Saúde Coletiva, São Paulo, São Paulo, Brazil.

${ }^{2}$ Universidade de São Paulo, Escola de Enfermagem, Programa de Pós-Graduação em Enfermagem, São Paulo, São Paulo, Brazil.

${ }^{3}$ Universidade de São Paulo, Escola de Enfermagem de Ribeirão Preto, Ribeirão Preto, São Paulo, Brazil.

\section{ABSTRACT}

Objective: The objective of this study is to assess preconception health behaviors among Brazilian women, and analyze the effect of pregnancy planning status in carrying out preconception measures. Method: This is a cross-sectional quantitative study conducted with 807 women, of whom 649 had a planned or ambivalent pregnancy. Preconception health behaviors were assessed by the Brazilian version of the London Measure of Unplanned Pregnancy. Results: Preconception health behaviors were performed by only $15.9 \%$ of women. Among those who planned their pregnancy, less than half completed a health measure (47.0\%); the most common was seeking medical assistance and improving the diet. Multiple logistic regression analysis showed a strong association between the preconception health behaviors and a planned pregnancy (adjusted OR $=16.77 ; 95 \%$ CI: 9.47-29.81). Age over 30 years, paid work, and the time interval between menarche and first sexual intercourse were also associated with completing preconception measures. Conclusion: The low frequency of preconception health measures, even among women who planned their pregnancy, indicates the urgency of including preconception care on the agenda of public health policies in Brazil.

\section{DESCRIPTORS}

Preconception Care; Pregnancy; Sexual and Reproductive Health; Maternal-Child Nursing.

\author{
Corresponding author: \\ Ana Luiza Vilela Borges \\ Departamento de Enfermagem \\ em Saúde Coletiva/EEUSP \\ Av. Dr. Enéas de Carvalho Aguiar, 419 \\ Cerqueira César \\ CEP 05403-000 - São Paulo, SP, Brasil \\ alvilela@usp.br
}

Received: 08/24/2015

Approved: 12/27/2015 


\section{INTRODUCTION}

The preconception period is crucial to the development of a healthy pregnancy, and therefore health promotion and disease prevention actions should be fully implemented before conception occurs. These actions consist of preconception care, which is defined as "the provision of health-related biomedical, behavioral, and social interventions in the period before conception, which aim to improve health status and reduce behaviors and factors that contribute to poor outcomes of maternal and child health"(1) and include the promotion of adequate food and nutrition, the promotion of a safe environment, prevention and control of diseases, genetic counseling, mental health promotion, identification of poor living conditions and interpersonal violence, prevention of licit and illicit drug use, prevention of successive pregnancies, and infertility treatment ${ }^{(1)}$.

Despite the importance of completing preconception health behaviors for the promotion of maternal and child health ${ }^{(1)}$, studies show that it is still not frequent ${ }^{(2-5)}$, mainly because of its close relationship to pregnancy planning. Women who plan their pregnancies are more likely to have preconception health behaviors ${ }^{(6-8)}$, although not all of them take any action whatsoever to prepare for pregnancy ${ }^{(2-4,9)}$. Other non-individual aspects may determine the adoption of preconception health behaviors, like health services organization $^{(10)}$ and the lack of awareness of health professionals ${ }^{(5)}$ and women themselves ${ }^{(11-12)}$ about its importance. From an individual point of view, schooling, marital status, and reproductive experience are also key factors on the uptake of preconception care $^{(9)}$.

Most of the studies conducted on preconception health behaviors were carried out in countries with high proportions of planned pregnancies and an adequate supply of preconception care ${ }^{(2-4,9)}$. Little is known about its prevalence in countries like Brazil, where the proportion of planned pregnancies is still low ${ }^{(13)}$ and the provision of this service is fledgling. Thus, the aims of this study were to measure the proportion of women who performed preconception health behaviors, to describe the measures adopted during preconception period, and to analyze the effect of pregnancy planning status and other sociodemographic characteristics in adopting preconception health behaviors. Our hypothesis is that pregnancy planning is the main determinant of preconception health behaviors adoption, but other sociodemographic characteristics also contribute.

\section{METHOD}

This is a cross-sectional quantitative study conducted through data pooling from three studies carried out in the city of São Paulo, Brazil. The first study was also quantitative and cross-sectional, whose population consisted of 511 pregnant women, irrespective of pregnancy trimester, attending 12 Basic Health Care Facilities in $2013^{(14)}$. The second study was longitudinal and quantitative, whose population consisted of 170 women hospitalized for abortion in a public maternity hospital between May and December $2011^{(15)}$, and the data used here were collected during hospitalization. The third one was a cross-sectional quantitative study, conducted with 126 teenagers 13 to 19 years old, also in a public maternity hospital, from January to June 2012, during prenatal and postpartum care ${ }^{(16)}$.

To estimate the proportion of women who carried out preconception health behaviors, all women from the three studies were considered $(n=807)$. To describe the preconception health behaviors adopted by women, and to analyze the effect of pregnancy planning status in adopting preconception health behaviors, all women with unplanned pregnancies were excluded $(n=158)$, because no preconception measure is expected among women who do not plan their pregnancies, which, in fact, was verified (no woman with an unplanned pregnancy reported having taken any preconception measure). Thus, 649 women with planned $(n=219)$ or ambivalent $(n=430)$ pregnancies were considered. The pregnancy status and study scenario were as follows: Study 1 had 28.7\% of women with planned pregnancies, $52.6 \%$ with ambivalent pregnancies, and $18.7 \%$ with unplanned pregnancies; Study 2 had $29.4 \%$ of women with planned pregnancies, $48.2 \%$ with ambivalent pregnancies, and $22.4 \%$ with unplanned pregnancies; and Study 3 had $18.3 \%$ of women with planned pregnancies, $62.7 \%$ with ambivalent pregnancies, and $19.0 \%$ with unplanned pregnancies.

Pregnancy planning status (planned, ambivalent, and unplanned) was classified in accordance with the Brazilian version $^{(17)}$ of the instrument for measurement of pregnancy planning, called London Measure of Unplanned Pregnancy (LMUP), used in a standardized way in all 3 studies.

The LMUP is a short and self-applicable instrument, consisting of six items that make up the pregnancy planning domain. These items are grouped into three aspects: intention, composed of the desire to become a mother and the expressed intention of getting pregnant; context, composed of the influence (or lack of ) from the partner and personal circumstances, such as material resources, stage of life, and kind of affective or loving relationship; and behavior, comprising the use of contraceptive methods and preconception preparation for pregnancy, such as the use of folic acid, the adoption of a healthier diet, and a decrease in smoking. This is a valid and feasible measure for any type of pregnancy, regardless of the outcome. The score is calculated by summing the points, which range from 0 to 2 for each item, with a maximum total of 12 points. The authors classify the pregnancy according to the total points: 10 to 12 points (planned pregnancy); 4 to 9 points (ambivalent about the planning of pregnancy), and 0 to 3 (unplanned pregnancy)(18).

One of the LMUP advantages is its classification of pregnancies beyond the artificial dichotomy of "planned" or "unplanned," because it allows the classification of an ambivalent pregnancy. This means that the instrument does not ignore the complexity of women's experiences related to reproduction, including ambivalence or uncertainty ${ }^{(19-20)}$. In fact, qualitative studies have shown that women have ambivalent, contradictory, or unspecific attitudes and intentions, and that they face varying degrees of conviction in the 
process of becoming pregnant or preventing pregnancy ${ }^{(21-22)}$. An example is that the non-use of contraceptive methods does not always correspond to the expressed intention of becoming pregnant ${ }^{(23)}$.

In the analysis, the dependent variable was considered the adoption of preconception health behaviors, measured by the sixth question of the LMUP: "Before you got pregnant, did you take any measure/initiative to improve your health to prepare for this pregnancy?" The suggested answers were: "I took folic acid," "I quit/reduced smoking," "I quit/reduced alcoholic drinking," "I ate healthier," II sought medical assistance or other health services," "I took other actions, (please describe:______ ), and "I didn't do any of this before pregnancy." The variable "adoption of preconception health behaviors" was then categorized dichotomously, in which women who reported any measure (one or more than one) were grouped in the category "yes," and those who reported not having done anything before pregnancy were grouped in the category "no." It should be noted that this question concerned the ongoing pregnancy or the one ending in abortion (induced or miscarriage) or birth.

The independent variables were pregnancy planning status ("planned" and "ambivalent"); age (categorized as 13-19, 20-25, 26-30, or 31 and over); schooling (in years); marital status ("living with partner" or "not living with partner"); current paid job ("yes" or "no"); and race/ethnicity ("white" or "non-white"). Variables concerning reproductive history were the number of pregnancies ("one," "two," or "three or more"); the time interval between menarche and first sexual intercourse (in years); and the time interval between age at first sexual intercourse and age at first pregnancy (in years). The variable "previous abortion" ("yes" or "no") was included only for sample description.

Data were analyzed using Stata 13.0. Categorical variables were described by absolute numbers and proportions, and the quantitative variables by means and standard deviations. The differences between two proportions were analyzed using the chi-square test, and the differences between the medians by the Mann-Whitney test.

To analyze the determinants of the adoption of preconception health behaviors, we conducted three independent models of multiple logistic regression, in which all variables were simultaneously included. Our aim with the first model (Model 1) was to measure the effect of pregnancy planning status in completing preconception health behavior, so we conducted it considering pregnancy planning status (planned or ambivalent) as the most important explanatory variable. The second model (Model 2) was conducted in order to identify the effect of other aspects, such as sociodemographic and reproductive characteristics, in the completion of preconception health behaviors; thus, we did not use pregnancy planning status as an adjustment variable within this model. The third model (Model 3) was conducted only with women who had planned their pregnancies, and our aim was to identify aspects associated to the completion of preconception health behaviors among them. The significance level considered was of $5 \%$ for all analyzes. The strength of association between the dependent variable and the independent variables was evaluated by the adjusted odds ratio (adjusted OR).

In all three studies, participants under 18 years of age were formally authorized by their parents or guardians to participate. The studies were approved by the Research Ethics Committee of the Escola de Enfermagem of Universidade de São Paulo (EE/USP) under CAAE no. 08528412.8.0000.5392, CAAE no. 0094.0.196.196611, and CAAE no. 0011.0.196.255-11, and we obtained the approval of the health institutions where they were carried out, in addition to the written consent of the women interviewed.

\section{RESULTS}

Considering the 807 participants from the three studies, $15.9 \%$ reported at least one preconception health behavior $(n=128)$. When considering the 647 women with planned or ambivalent pregnancy, the proportion was higher, $19.8 \%$. In turn, when considering only women with planned pregnancies, the proportion of those carrying out preconception preparation was $47.0 \%(n=103)$.

When we excluded women with unplanned pregnancies, we observed that, among women who reported preconception health behaviors, $80.5 \%$ had planned pregnancies. More than half of these women were up to 25 years of age and had 9.6 years of schooling, on average, and most of them lived with a partner. A bit more than half reported having paid jobs, just over one-third reported a previous abortion, and almost half got pregnant only once. A third of our sample actually reported a planned pregnancy. The bivariate analysis showed a statistically significant difference in preconception health behaviors in relation to pregnancy planning status, age, and paid job. The median level of schooling, the time interval between menarche and first sexual intercourse, and the median time interval between age at first sexual intercourse and age of first pregnancy were statistically different between the group that reported preconception health behavior and the group that did not report it (Table 1 ).

Table 2 shows the measures adopted as preconception health behaviors. First of all, it is noteworthy that women with planned pregnancies reported, in greater proportion, more preconception health behaviors compared to all women in the study or women with ambivalent pregnancy. Secondly, the main measures adopted as preconception health behaviors were similar between the groups. The most common were to have sought medical assistance, followed by having started to eat healthier. The proportion of women who reported folic acid uptake was 5.6\% when considering all women in the study, and $18.3 \%$ among women with planned pregnancies. Some women reported measures other than the options offered in the instrument, such as financial planning for pregnancy, avoiding situations of stress, getting better sleep, engaging in physical activities, avoiding drug use, controlling preexisting conditions, undergoing pregestational examinations, and infertility treatment. 
Table 1 - Sociodemographic and reproductive characteristics of women according to preconception health behavior - São Paulo, São Paulo, Brazil, 2011-2013.

\begin{tabular}{|c|c|c|c|c|c|c|c|}
\hline \multirow{3}{*}{ Variables } & \multicolumn{7}{|c|}{ Preconception health behavior } \\
\hline & \multicolumn{2}{|c|}{ No } & \multicolumn{2}{|c|}{ Yes } & \multicolumn{2}{|c|}{ Total } & \multirow[t]{2}{*}{$\mathbf{p}^{*}$} \\
\hline & $\mathbf{n}$ & $\%$ & $\mathbf{n}$ & $\%$ & $\mathbf{N}$ & $\%$ & \\
\hline \multicolumn{8}{|c|}{ Pregnancy planning status } \\
\hline Ambivalent & 405 & 77.7 & 25 & 19.5 & 430 & 66.3 & $<0.001$ \\
\hline Planned & 116 & 22.3 & 103 & 80.5 & 219 & 33.7 & \\
\hline \multicolumn{8}{|l|}{ Age (in years) } \\
\hline $13-19$ & 160 & 30.7 & 24 & 18.8 & 184 & 28.4 & $<0.001$ \\
\hline $20-25$ & 146 & 28.0 & 26 & 20.3 & 172 & 26.5 & \\
\hline $26-30$ & 101 & 19.4 & 27 & 21.1 & 128 & 19.7 & \\
\hline 31 and over & 114 & 21.9 & 51 & 39.8 & 165 & 25.4 & \\
\hline \multicolumn{8}{|l|}{ Lives with partner } \\
\hline No & 101 & 19.4 & 16 & 12.5 & 117 & 18.0 & 0.069 \\
\hline Yes & 420 & 80.6 & 112 & 87.5 & 532 & 82.0 & \\
\hline \multicolumn{8}{|l|}{ Paid job } \\
\hline No & 277 & 53.2 & 46 & 35.9 & 323 & 49.8 & $<0.001$ \\
\hline Yes & 244 & 46.8 & 82 & 64.1 & 326 & 50.2 & \\
\hline \multicolumn{8}{|l|}{ Race/ethnicity } \\
\hline White & 350 & 67.2 & 79 & 61.7 & 429 & 66.1 & 0.242 \\
\hline Non-white & 171 & 32.8 & 49 & 38.3 & 220 & 33.9 & \\
\hline \multicolumn{8}{|c|}{ Number of pregnancies } \\
\hline One & 244 & 46.8 & 60 & 46.9 & 304 & 46.8 & 0.981 \\
\hline Two & 143 & 27.5 & 36 & 28.1 & 179 & 27.6 & \\
\hline Three or more & 134 & 25.7 & 32 & 25.0 & 166 & 25.6 & \\
\hline \multicolumn{8}{|l|}{ Previous abortion } \\
\hline No & 335 & 64.3 & 81 & 63.3 & 416 & 64.1 & 0.830 \\
\hline Yes & 186 & 35.7 & 47 & 36.7 & 233 & 35.9 & \\
\hline \multirow[t]{2}{*}{ Total } & 521 & 100.0 & 128 & 100.0 & 649 & 100.0 & \\
\hline & Mean & $\mathbf{s d}^{* *}$ & Mean & sd & Mean & sd & $\mathbf{p}^{* * *}$ \\
\hline Schooling (years) & 9.5 & 2.4 & 10.0 & 2.4 & 9.6 & 2.4 & 0.026 \\
\hline Interval $1 * * * *$ & 3.6 & 2.5 & 4.8 & 3.2 & 3.8 & 2.7 & $<0.001$ \\
\hline Interval $2^{* * * * *}$ & 3.8 & 3.7 & 4.9 & 4.4 & 4.0 & 3.8 & 0.017 \\
\hline
\end{tabular}

* Chi-square test; ${ }^{* *}$ sd: standard deviation; ${ }^{* * * *}$ Mann-Whitney test; ${ }^{* * * * *}$ Time interval between menarche and first sexual intercourse (in years); ${ }^{* * * * * * *}$ Time interval between the age at first sexual intercourse and at first pregnancy (in years) 
Table 2 - Distribution of women who reported preconception health behaviors according to the measures adopted - São Paulo, São Paulo, Brazil, 2011-2013.

\begin{tabular}{|c|c|c|c|c|c|c|}
\hline \multirow[t]{2}{*}{ Preconception health behaviors } & \multicolumn{2}{|c|}{$\begin{array}{l}\text { All women* } \\
(\mathbf{n}=\mathbf{8 0 7})\end{array}$} & \multicolumn{2}{|c|}{$\begin{array}{l}\text { Women with } \\
\text { planned pregnancy } \\
(\mathrm{n}=219)\end{array}$} & \multicolumn{2}{|c|}{$\begin{array}{c}\text { Women with } \\
\text { ambivalent } \\
\text { pregnancy } \\
(\mathrm{n}=430)\end{array}$} \\
\hline & $\mathbf{n}$ & $\%$ & $\mathbf{n}$ & $\%$ & $\mathbf{n}$ & $\%$ \\
\hline One measure & 62 & 7.7 & 43 & 19.6 & 19 & 4.4 \\
\hline Two or more measures & 66 & 8.2 & 60 & 27.4 & 6 & 1.4 \\
\hline \multicolumn{7}{|l|}{ Types of measures** } \\
\hline Sought medical assistance & 72 & 8.9 & 63 & 28.8 & 9 & 2.1 \\
\hline Started eating healthier & 55 & 6.8 & 47 & 21.5 & 8 & 1.9 \\
\hline Took folic acid & 45 & 5.6 & 40 & 18.3 & 5 & 1.2 \\
\hline Stopped/reduced alcoholic drinking & 17 & 2.1 & 12 & 5.5 & 5 & 1.2 \\
\hline Stopped/reduced smoking & 15 & 1.8 & 13 & 5.9 & 2 & 0.5 \\
\hline Other actions $* * *$ & 34 & 4.2 & 31 & 14.1 & 3 & 0.7 \\
\hline
\end{tabular}

Table 3 shows the multiple logistic regression models. Model 1 confirms our hypothesis that pregnancy planning is the main determinant of preconception health behavior adoption, because no other aspect had a statistically significant effect. In Model 2, which does not consider the effect of pregnancy planning, paid job, age, and the time interval between age at menarche and first sexual intercourse were statistically associated with the report of preconception health behavior. In Model 3, which considers only women who planned their pregnancies, no variable was statistically significant, meaning none had an effect on the adoption of preconception health behaviors.

Table 3 - Multiple logistic regression models to analyze the adoption of preconception health behaviors - São Paulo, São Paulo, Brazil, 2011-2013.

\begin{tabular}{|c|c|c|c|c|c|c|}
\hline \multirow{2}{*}{ Variables } & \multicolumn{2}{|c|}{ Model 1} & \multicolumn{2}{|c|}{ Model 2} & \multicolumn{2}{|c|}{ Model 3} \\
\hline & Adj OR & CI $95 \%$ & Adj OR & Cl $95 \%$ & Adj OR & Cl $95 \%$ \\
\hline \multicolumn{7}{|c|}{ Pregnancy planning status } \\
\hline $\begin{array}{l}\text { Ambivalent } \\
\text { Planned }\end{array}$ & $\begin{array}{c}1.00 \\
16.77\end{array}$ & $\stackrel{-}{9.45-29.76}$ & & & & \\
\hline \multicolumn{7}{|l|}{ Age (in years) } \\
\hline $13-19$ & 1.00 & - & 1.00 & - & 1.00 & - \\
\hline $20-25$ & 0.56 & $0.25-1.26$ & 0.95 & $0.47-1.92$ & 1.62 & $0.52-5.06$ \\
\hline $26-30$ & 0.67 & $0.25-1.83$ & 1.41 & $0.60-3.28$ & 1.70 & $0.44-6.48$ \\
\hline 31 or more & 0.94 & $0.32-2.72$ & 2.57 & $1.03-6.39$ & 2.28 & $0.56-9.34$ \\
\hline Schooling (in years) & 1.08 & $0.97-1.20$ & 1.03 & $0.94-1.13$ & 1.11 & $0.98-1.26$ \\
\hline \multicolumn{7}{|l|}{ Lives with partner } \\
\hline $\begin{array}{l}\text { No } \\
\text { Yes }\end{array}$ & $\begin{array}{l}1.00 \\
0.58\end{array}$ & $0.28-1.19$ & $\begin{array}{l}1.00 \\
1.37\end{array}$ & $0.75-2.51$ & $\begin{array}{l}1.00 \\
0.40\end{array}$ & $0.11-1.45$ \\
\hline \multicolumn{7}{|l|}{ Paid job } \\
\hline $\begin{array}{l}\text { No } \\
\text { Yes }\end{array}$ & $\begin{array}{l}1.00 \\
1.38\end{array}$ & $0.82-2.33$ & $\begin{array}{l}1.00 \\
1.60\end{array}$ & $1.02-2.51$ & $\begin{array}{l}1.00 \\
1.18\end{array}$ & $0.63-2.21$ \\
\hline \multicolumn{7}{|l|}{ Race/ethnicity } \\
\hline $\begin{array}{l}\text { Non-white } \\
\text { White }\end{array}$ & $\begin{array}{l}1.00 \\
0.84\end{array}$ & $0.52-1.37$ & $\begin{array}{l}1.00 \\
1.07\end{array}$ & 0.70-1.65 & $\begin{array}{l}1.00 \\
0.93\end{array}$ & - \\
\hline \multicolumn{7}{|c|}{ Number of pregnancies } \\
\hline One & 1.00 & - & 1.00 & - & 1.00 & - \\
\hline
\end{tabular}




\begin{tabular}{lcccccc}
\hline \multirow{2}{*}{ Variables } & \multicolumn{2}{c}{ Model 1 } & \multicolumn{2}{c}{ Model 2 } & \multicolumn{2}{c}{ Model 3 } \\
\cline { 2 - 7 } & Adj OR & CI 95\% & Adj OR & CI 95\% & Adj OR & CI 95\% \\
\hline Two & 0.90 & $0.46-1.78$ & 0.74 & $0.41-1.35$ & 0.80 & $0.36-1.81$ \\
Three or more & 0.83 & $0.35-1.95$ & 0.56 & $0.27-1.20$ & 0.88 & $0.32-2.43$ \\
Interval 1* & 1.07 & $0.98-1.17$ & 1.10 & $1.02-1.19$ & 1.05 & $0.95-1.15$ \\
Interval 2** & 0.98 & $0.90-1.05$ & 1.00 & $0.93-1.06$ & 0.97 & $0.89-1.06$ \\
\hline
\end{tabular}

* Time interval between menarche and first sexual intercourse (in years); ${ }^{*}$ Time interval between the age at first sexual intercourse and at first pregnancy (in years). Model 1: considers the effect of pregnancy planning; Model 2: does not consider the effect of pregnancy planning; Model 3: considers only women with planned pregnancies. HosmerLemeshow test: Model $1=0.83 ;$ Model $2=0.41 ;$ Model $3=0.25$.

\section{DISCUSSION}

Only one-sixth of our sample carried out some sort of preconception health behaviors. This is a finding of difficult comparison, given that the majority of studies evaluate preconception behavior adoption through one or two specific measures, such as the uptake of folic acid or other vitamin supplements. When evaluating preconception health behaviors in a general perspective, we assume that the preconception measures to improve health during pregnancy make up a broader framework of actions to promote health for women and their children than just one or two measures. When considering only women who had planned pregnancies, the proportion of those who adopted some sort of preconception health behaviors was higher, as expected, because they are associated events ${ }^{(5)}$. Similarly, studies conducted in developed countries, such as in the United States and France, show similar results to those observed in our study ${ }^{(3-4)}$.

Specifically related to the preconception measures, the low proportion of folic acid uptake draws attention, even when considered it was slightly larger than the $4.3 \%$ previously observed in southern Brazil in $2007^{(24)}$. Although folic acid supplementation is still recommended in the three months preceding pregnancy and in the first trimester of pregnancy, our findings suggest that it is still scarcely practiced among pregnant women in the country. Anyway, in Brazil, there has been a great improvement regarding the intake of folic acid since the Brazilian government established the mandatory fortification of wheat and maize flour with iron and folic acid, which brought about positive results in preventing neural tube defects ${ }^{(25)}$.

Our results also show that the demand for medical assistance was the most cited preconception measure, which is an important issue, as women who undergo counseling by health professionals before pregnancy are more likely to adopt preconception health behaviors ${ }^{(5)}$. However, undergoing medical examination before conception does not necessarily mean that women are receiving counseling to prepare for becoming pregnant. A study conducted in France in 2014 shows that most women who underwent medical consultation before conception had not received a prescription for folic acid supplementation ${ }^{(3)}$. In this context, there is, certainly, a need for greater engagement and training of health professionals to promote preconception health behaviors.
In addition, other preconception measures were reported, such as the establishment of a financial reserve and the practice of physical exercise. This seems that there is a wider range of practices that permeates the social knowledge other than just those expressed in health guidelines. These measures can also be understood as part of preconception preparation among Brazilian women. Even in low proportions, some women are really motivated to adopt measures to support a healthy pregnancy.

Just as observed elsewhere ${ }^{(4,6-8)}$, our findings confirm that pregnancy planning is an important condition for the adoption of preconception health behaviors. However, most of studies are carried out in countries where the proportion of planned pregnancy is greater than $70 \%^{(2-5)}$, whereas, in Brazil, planned pregnancy are not frequent yet. Despite the fact that there are differences in the instruments that measure pregnancy intention, a national study ${ }^{(13)}$ showed that almost half of pregnancies were unwanted or mistimed. We have no doubt that if every Brazilian woman has the opportunity to plan a pregnancy, the adoption of preconception health behaviors will increase.

In addition to the strong relation between pregnancy planning status and preconception health behavior, our results also showed that women who are more likely to adopt preconception measures are older, are engaged in paid jobs, and have a greater time interval between menarche and first sexual intercourse. Regarding age, a study in Brazil found that this variable was associated with the use of folic acid ${ }^{(24)}$, which was also reported in other studies ${ }^{(4-5)}$. In line with this, having paid job also proved to be determinant in the adoption of some preconception measures, which was also highlighted earlier ${ }^{(5)}$. Both age over 30 years and paid job can shape a condition of greater autonomy and motivation for women to seek more information about a healthy pregnancy and thus adopt preconception health behaviors.

The close relationship between preconception health behaviors and pregnancy planning status can also explain the statistical significance observed in relation to the time interval between menarche and first sexual intercourse. The occurrence of the first sexual intercourse before the age of 16 is directly related to the occurrence of an unplanned pregnan$\mathrm{cy}^{(26)}$. Statistically significant variables in the model conducted without the effect of pregnancy planning were precisely those that, in theory, are determinants in the occurrence of planned pregnancies. Therefore, their effect on the completion of preconception measures may have been through the 
interaction with the planning of the pregnancy. Anyway, carrying out three statistical models was an advantage of this study, as they allowed the identification of the effect of pregnancy planning in adopting preconception health behaviors.

This study has some limitations. The first one is that data are from studies with different objectives, which also configures several sampling plans. Although this aspect represents a restriction regarding the inference of these sample data to the general population, the findings are relevant because it is a subject largely ignored in the reproductive health field in Brazil. In turn, this study included women with different experiences of pregnancy, such as pregnancies ended at term or abortions, nulliparous and multiparous women, teenagers, and older women, which allowed investigation into what extent the effects of reproductive experience overlap the effects of pregnancy planning in preconception health behaviors.

Another limitation is that the effect of access to preconception care was not measured, but it is necessary to consider that all women interviewed were users of the National Unified Health System. Future studies should investigate the reason why some Brazilian women who plan pregnancy do not adopt preconception health behaviors, including the role played by public and private health services. Neither was it possible to analyze whether or not there are differences in preconception measures between different social status groups, although schooling and paid job were considered for adjustment of the models.

The strengths of our study is that we measured pregnancy planning status with a robust instrument, which was adapted to and validated in Brazil, as well as to other cultural contexts, with good psychometric properties ${ }^{(23,27-28)}$. Although it was not our aim, it is necessary to advance the understanding of the effect of ambivalent pregnancy on preconception health behaviors and, above all, on other reproductive health indicators, especially because most women were classified in this group.

In the context of the scant attention to the preconception period, as in the case of Brazil, providing conditions for women to plan their pregnancy is a viable and effective way to promote the adoption of preconception health behaviors. However, this may not be enough, given that the adoption of preconception measures does not solely derive from an individual decision, but is intrinsically related to the access to health services that offer preconception care. This is still incipient in Brazil and it is not known how it is established, but it certainly does not yet constitute a priority in health services; other interventions during the pregnancy period are prioritized in the context of primary health care, such as prenatal care ${ }^{(29)}$. This context may have played an important role in the low proportion of preconception health measures reported in this study.

\section{CONCLUSION}

Preconception health behavior is essential for the development of a healthy pregnancy. This study confirms the strong relationship between the adoption of preconception health measures and pregnancy planning status. Considering the relatively low proportion of planned pregnancies in Brazil, it is necessary that women and couples are encouraged to plan their reproductive lives. This study also shows that not all women who planned their pregnancy completed preconception measures, which indicates that preconception care should be part of health services' routine actions straightway.

\section{RESUMO}

Objetivo: Mensurar a realização do preparo pré-concepcional, descrever as medidas adotadas como preparo pré-concepcional e analisar o efeito do planejamento da gravidez na realização do preparo pré-concepcional. Método: Estudo quantitativo, do tipo transversal, conduzido com 807 mulheres, das quais 649 tinham gravidez planejada ou ambivalente. O preparo pré-concepcional foi mensurado a partir do London Measure of Unplanned Pregnancy, versão Brasil. Resultados: O preparo pré-concepcional foi realizado por apenas $15,9 \%$ das mulheres. Dentre as que planejaram a gravidez, menos da metade realizou algum preparo (47,0\%), sendo os mais frequentes ter procurado assistência médica e mudanças na alimentação. Análise de regressão logística múltipla mostrou forte associação entre a realização do preparo pré-concepcional e o planejamento da gravidez (ORajustado=16,77; IC95\% 9,47-29,81). A idade acima de 30 anos, o trabalho remunerado e o intervalo de tempo entre a menarca e a primeira relação sexual também estiveram associados à realização do preparo pré-concepcional. Conclusão: A baixa frequência de realização de preparo pré-concepcional, mesmo entre mulheres com gravidez planejada, indica a urgência de se incluir o cuidado pré-concepcional na agenda de políticas públicas de saúde.

\section{DESCRITORES}

Cuidado Pré-Concepcional; Gravidez; Saúde Sexual e Reprodutiva; Enfermagem Materno-Infantil.

\section{RESUMEN}

Objetivo: Medir la realización de la preparación pre concepcional, describir las medidas adoptadas como preparación pre concepcional y analizar el efecto de la planificación del embarazo en la preparación pre concepcional. Método: Estudio cuantitativo, del tipo transversal, conducido con 807 mujeres, de las cuales 649 tenían embarazo planificado o ambivalente. La preparación pre concepcional fue medida mediante el London Measure of Unplanned Pregnancy, versión Brasil. Resultados: La preparación pre concepcional fue realizada por solo el 15,9\% de las mujeres. Entre las que planificaron el embarazo, menos de la mitad realizó alguna preparación (47,0\%), siendo las más frecuentes haber buscado asistencia médica y cambios en la alimentación. El análisis de regresión logística múltiple mostró fuerte asociación entre la realización de la preparación pre concepcional y la planificación del embarazo (ORajustado=16,77; IC95\% $9,47-29,81)$. La edad superior a 30 años, el trabajo remunerado y el intervalo de tiempo entre la menarca y la primera relación sexual también estuvieron asociados con la realización de la preparación pre concepcional. Conclusión: La baja frecuencia de realización de preparación pre concepcional, aun entre mujeres con embarazo planificado, señala la urgencia de incluirse el cuidado pre concepcional en la agenda de políticas públicas de salud.

\section{DESCRIPTORES}

Atención Preconceptiva; Embarazo; Salud Sexual y Reproductiva; Enfermería Maternoinfantil. 


\section{REFERENCES}

1. World Health Organization. Meeting to develop a global consensus on preconception care to reduce maternal and childhood mortality and morbidity. Geneva: WHO; 2012.

2. Backhausen MG, Ekstrand M, Tydén T, Magnussen BK, Shawe J, Stern J, et al. Pregnancy planning and lifestyle prior to conception and during early pregnancy among Danish women. Eur J Contracept Reprod Health Care. 2014;19(1):57-65.

3. Luton D, Forestier A, Courau S, Ceccaldi PF. Preconception care in France. Int J Gynaecol Obstet. 2014;125(2):144-5.

4. Rosenberg KD, Gelow JM, Sandoval AP. Pregnancy intendedness and the use of periconceptional folic acid. Pediatrics. 2003;111 (5 Pt 2):1142-5.

5. Stephenson J, Patel D, Barrett G, Howden B, Copas A, Ojukwu O, et al. How Do Women Prepare for Pregnancy? Preconception Experiences of Women Attending Antenatal Services and Views of Health Professionals. PLoS One. 2014;9(7): e103085.

6. Dott M, Rasmussen SA, Hogue CJ, Reefhuis J; National Birth Defects Prevention Study. Association between pregnancy intention and reproductive-health related behaviors before and after pregnancy recognition, National Birth Defects Prevention Study, 1997-2002. Matern Child Health J. 2010;14(3):373-81.

7. Gong R, Wang ZP , Gao LJ , Lu QB , Sun XH , Zhao ZT . A case-control study of the effects of pregnancy planning on neural tube defects and its primary preventive measures. Birth Defects Res A Clin Mol Teratol. 2010;88(9):737-42.

8. Wender-Ozegowska E, Gutaj P, Szczepanek U, Ozegowska K, Zawiejska A, Brazert J. Influence of pregnancy planning on obstetrical results in women with pregestational diabetes mellitus. Ginekol Pol. 2010;81(10):762-7.

9. De Santis M, Quattrocchi T, Mappa I, Spagnuolo T, Licameli A, Chiaradia G, et al. Folic acid use in planned pregnancy: an Italian survey. Matern Child Health J. 2013; 17(4):661-6.

10. Johnson KA. Public finance policy strategies to increase access to preconception care. Matern Child Health J. 2006; 10 Suppl 1:85-91.

11. Canady RB, Tiedje LB, Lauber C. Preconception care \& pregnancy planning: voices of African American women. MCN Am J Matern Child Nurs. 2008;33(2):90-7.

12. Van der Zee B, de Beaufort ID, Steegers EA, Denktas S. Perceptions of preconception counselling among women planning a pregnancy: a qualitative study. Fam Pract. 2013;30(3):341-6.

13. Brasil. Ministério da Saúde. Pesquisa Nacional de Demografia e Saúde da Criança e da Mulher - PNDS 2006. Relatório. Brasília: MS; 2008.

14. Santos AO, Borges ALV, Chofakian CBN, Pirotta KCM. Determinants of emergency contraception non-use among women in unplanned or ambivalent pregnancies. Rev Esc Enferm USP. 2014;48(n.spe):16-22.

15. Borges ALV, Monteiro RL, Hoga LAK, Fujimori E, Chofakian CBN, Santos AO. Post-abortion contraception: care and practices. Rev Latino Am Enfermagem. 2014; $22(2): 293-300$.

16. Nascimento NC, Borges ALV, Santos AO, Chofakian CBN, Fujimori E. Preparo pré-concepcional entre adolescentes grávidas: conhecimento e prática. Rev Enferm UFPE. 2015;9(5):7895-901.

17. Borges ALV, Cavalhieri FB, Hoga LAK, Fujimori E, Barbosa LR. Pregnancy planning: prevalence and associated aspects Rev Esc Enferm USP. 2011;45(2):1679-84

18. Barrett G, Smith SC, Wellings K. Conceptualisation, development and evaluation of a measure of unplanned pregnancy. J Epidemiol Community Health. 2004;58(5):426-33.

19. Schwarz EB, Lohr PA, Gold MA, Gerbert B. Prevalence and correlates of ambivalence towards pregnancy among nonpregnant women. Contraception. 2007; 75(4):305-10.

20. Crosby RA, DiClemente RJ, Wingood GM, Davies SL, Harrington R. Adolescents' ambivalence about becoming pregnant predicts infrequent contraceptive use: a prospective analysis of nonpregnant African American females. Am J Obstet Gynecol. 2002;186(2):251-2.

21. Barret G, Wellings K. What is a planned pregnancy? Empirical data from a British study. Soc Sci Med. 2002;55(4):545-57.

22. Kendall C, Afable AM, Speizer I, Avery A, Schmidt N, Santelli J. Understanding pregnancy in a population of inner-city women in New Orleans: results of qualitative study. Soc Sci Med. 2005;60(2):297-311.

23. Rocca CH, Krishnan S, Barrett G, Wilson M. Measuring pregnancy planning: an assessment of the London Measure Unplanned Pregnancy among urban, south Indian women. Demogr Res. 2010;23:293-34.

24. Mezzomo CLS, Garcias GL, Sclowitz ML, Sclowitz IT, Brum CB, Fontana T et al. Prevenção de defeitos do tubo neural: prevalência do uso da suplementação de ácido fólico e fatores associados em gestantes na cidade de Pelotas, Rio Grande do Sul, Brasil. Cad Saúde Pública. 2007;23(11):2716-26.

25. Fujimori E, Baldino CF, Sato APS, Borges ALV, Gomes MN. Prevalência e distribuição espacial de defeitos do tubo neural no Estado de São Paulo, Brasil, antes e após a fortificação de farinhas com ácido fólico. Cad Saúde Pública. 2013;29(1):145-54.

26. Wellings K, Jones KG, Mercer $\mathrm{CH}$, Tanton $\mathrm{C}$, Clifton S, Datta J, et al. The prevalence of unplanned pregnancy and associated factors in Britain: findings from the third National Survey of Sexual Attitudes and Lifestyles (Natsal-3). Lancet. 2013; 382(9907):1807-16.

27. Hall J, Barrett G, Mdwana N, Copas A, Malata A, Stephenson J. Understanding pregnancy planning in a low-income country setting: validation of the London Measure of Unplanned Pregnancy in Malawi. BMC Pregnancy Childbirth. 2013; 13:200.

28. Morof D, Steinauer J, Haider S, Liu S, Darney P, Barrett G. Evaluation of the reliability and validity of the London Measure of Unplanned Pregnancy in a U.S. population of women. Int J Gynecol Obstet. 2009;107 Suppl 2:S275.

29. Moura ERF, Silva RM, Galvão MTG. Dinâmica do atendimento em planejamento familiar no Programa de Saúde da Família no Brasil. Cad Saúde Pública. 2007;23(4): 961-70. 